\title{
Maitotilojen kustannustehokkuus ja sen kehittäminen
}

\author{
Sami Ovaska ${ }^{1)}$, Timo Sipiläinen ${ }^{1)}$, Matti Ryhänen ${ }^{2)}$ \\ ${ }^{1)}$ MTT Taloustutkimus, Luutnantintie 13,00410 Helsinki, etunimi.sukunimi@mtt.fi \\ ${ }^{2)}$ Seinäjoen AMK, maa- ja metsätalouden yksikkö, Ilmajoentie 525, 60800 \\ Ilmajoki,matti.ryhanen@seamk.fi
}

\section{Tiivistelmä}

Maidontuottajat toimivat useiden teknisten, taloudellisten ja hallinnollisten rajoitteiden sekä kannustimien ympäristössä. Maidontuotannon tärkeimpiin ohjauskeinoihin on kuulunut tilakohtainen maitokiintiö, minkä vuoksi maitoa pyritään usein tuottamaan kiintiötä vastaava määrä mahdollisimman pienin yksikkökustannuksin. Benchmarkingin avulla pyritään kehittämään oman tilan toimintaa. Tämä tehdään vertaamalla oman tilan toimintaa tehokkaampiin vertailutiloihin ja ottamalla oppia niillä sovelletuista käytännöistä. Tällä hetkellä tilakohtaisia vertailuja käytetään laajasti ProAgrian neuvontatyössä. Tuotosseurannassa on mukana yli 11000 maitotilaa. Tätä laajempaa talousseurantaa (laaja Matu - maidontuotannon tuloslaskelma) tehdään vuosittain noin 2000 maitotilalla. Sen tavoitteena on tuottaa tuotannon ja talouden mittarilukuja tilan suorituskyvyn vertailuun suhteessa muihin tiloihin. Tilakunto on puolestaan ProAgrian internetpohjainen vertailupalvelu maitotiloille, missä seuraava kehitysaskel on parhailta tiloilta oppimisen tehostaminen.

Tutkimuksessa käytettiin DEA (Data Envelopment Analysis) -malleja, joiden avulla voidaan määrittää esimerkiksi maatilojen keskinäisiä suhteellisia tehokkuuksia (Färe ym. 1994; Coelli ym. 1998). Niiden avulla voidaan selvittää mahdollisuus vähentää panoskäyttöä ja/tai yksikkökustannuksia pitäen tuotos ennallaan.

Tulosten perusteella maitotilojen tekninen tehokkuus sekä kustannustehokkuus olivat suurilla tiloilla keskimäärin pieniä tiloja korkeammalla tasolla. Jos kaikki alle 25 lehmän tilat pystyisivät toimimaan yhtä tehokkaasti kuin aineiston parhaat tilat, niiden yksikkökustannukset alenisivat keskimäärin $33 \%$. Vastaavasti yli 70 lehmän tiloilla alennus olisi $18 \%$. On kuitenkin huomattava, että tehokkuuserot eivät aiheudu pelkästään viljelijän hallittavissa olevista tekijöistä. Tämän vuoksi eroja ei voida kokonaan poistaa.

Maidontuotannon yksikkökustannukset olivat yli 50 lehmän tiloilla keskimäärin 0,43 €/l (peltotuet vähennetty kotoisen rehun osalta). Pienillä alle 25 lehmän tiloilla vastaava luku oli keskimäärin $0,58 € /$. Tiloilla, joilla maidontuotannon kustannustehokkuus oli korkea, saavutettiin pääosin myös hyviä kannattavuuslukuja. Kustannustehokkuudeltaan aineiston 105 parhaasta tilasta 75 \% saavutti myös omalle työlle ja omalle pääomalle vaaditut korvaukset. Pienillä, alle 20 lehmän tiloilla, kustannustehokkuudet jäivät alhaiselle tasolle. Tähän kokoluokkaan kuului $35 \%$ aineiston tiloista, mutta kustannustehokkuudeltaan parhaimpien 105 tilan joukossa niiden osuus oli vain $7 \%$. Sen sijaan yli 50 lehmän tiloja oli aineistossa vain $5 \%$, mutta kustannustehokkaimpien tilojen joukossa niiden osuus oli $18 \%$. 


\section{Johdanto}

Maidontuottajat toimivat useiden teknisten, taloudellisten ja hallinnollisten rajoitteiden sekä kannustimien ympäristössä. Maidontuotannon tärkeimpiin ohjauskeinoihin on kuulunut tilakohtainen maitokiintiö. Usealla tilalla maitokiintiö on ohjannut viljelijän tavoitteita suuntaan, jossa tuotetaan maitoa kiintiötä vastaava määrä mahdollisimman pienin yksikkökustannuksin. Viljelijällä voi myös olla muita tavoitteita tilansa toiminnan ja sen kehittämisen suhteen yksikkökustannusten minimoinnin sijaan. Tämän vuoksi oletus viljelijän pyrkimisestä aina pelkästään yksikkökustannusten minimointiin onkin huomattava yksinkertaistus (mm. Hardaker ym. 1997).

Alin saavutettavissa oleva yksikkökustannus riippuu kahdesta tekijästä. Nämä ovat tuotettua yksikköä kohti käytettyjen tuotantopanosten määrät ja hinnat. Suomalaisten viljelijöiden on usein mahdotonta saavuttaa keskieurooppalaista yksikkökustannustasoa. Tähän vaikuttavat muun muassa lyhyt kasvukausi sekä pienet ja hajallaan sijaitsevat peltolohkot. Vaikka Suomessa ei yksikkökustannuksissa päästäkään keskieurooppalaiselle tasolle, saattavat samankaltaistenkin tilojen tulokset vaihdella merkittävästi. Osaan eroihin johtavista syistä viljelijä ei voi vaikuttaa. Tilan toimintaa voidaan kuitenkin usein kehittää ottamalla oppia parhaista sovelletuista käytännöistä eli benchmarkingilla. Jos käytettävissä on riittävästi havaintoja, voidaan vertailuun muodostaa sopivia ryhmiä esimerkiksi viljelijän omien mieltymysten perusteella.

Tilakohtaisia vertailuja käytetään apuna laajasti neuvontatyössä. Tilakunto, ProAgrian palvelu maitotiloille, on ollut käytössä tuotosseurantatiloilla vuoden 2004 alusta. Tuotosseurannassa on mukana yli 11000 maitotilaa, mikä vastaa lähes 70 \% kaikista maitotiloista. Sitä laajempaa talousseurantaa tehdään vuosittain noin 2000 maitotilalla. Tilakunnon tavoite on toimia yrittäjän apuvälineenä tilan toiminnan kehittämisessä ja johtamisessa. Viljelijä voi tarkastella omia ja vertailutietoja internetsivuilta (www.proagria.fi/verkkopalvelut). Vastaavankaltainen internetpohjainen tulosten vertailumahdollisuus on nykyisin myös MTT Taloustutkimuksen kannattavuuskirjanpitotiloilla. Maitotilojen osalta Tilakunnon seuraava kehitysaskel on parhailta tiloilta oppimisen tehostaminen. Tähän liittyy benchmarking-lähestymistavan ottaminen mukaan tarkasteluun. Tällöin yrittäjä pystyy arvioimaan omaa sijoittumistaan ja seuraamaan omaa kehittymistään muihin tiloihin verrattuna.

\section{Aineisto ja menetelmät}

Aineistona käytettiin ProAgrian maitotila-aineistoa vuodelta 2005 (laaja Matu) sisältäen 1661 maitotilan tiedot. Taulukossa 1 on esitetty aineiston maitotilojen keskeisiä ominaisuuksia. Lohkotietopankki puolestaan ProAgria Maaseutukeskusten Liiton kehittämä ja ylläpitämä internetissä käytettävä vertailupalvelu. Sen tavoitteena on tuottaa kasvintuotannon kehittämiseen ja päätöksentekoon tarvittavaa vertailutietoa Tilakuntopalvelun tavoin. Lohkotietopankin tietosisältö koostuu lohkokohtaisista muistiinpanoista: viljelytiedoista, tuotantopanosten käyttötiedoista ja -ajankohdista, sadon laatu- ja määrätiedoista sekä talouslaskelmista. Tiedot kerätään viljelymuistiinpanoista, satotuotteiden laatuanalyyseistä ja talouslaskelmista. Oman tilan tuloksia voidaan lisäksi vertailla muiden saman alueen, samalla maalajilla tai samaa viljelykasvia viljelevien tilojen tuloksiin. Viljelijä saa käyttöoikeuden vertailupalveluun toimittamalla oman tilan viljelytiedot Lohkotietopankkiin. Laajan Matun tiedot sisältävät vain navetan sisäisen toiminnan eivätkä tilan kasvintuotantoa, minkä vuoksi Lohkotietopankin peltoviljelytiedot yhdistettiin Matu-aineiston tiloihin. Tämän avulla saatiin lisätietoa myös peltoviljelystä 577 Matu-aineiston tilalta eli kolmasosalta tutkimustiloista.

Taulukko 1. Tutkimusaineiston (laaja MATU) maitotilojen ominaisuuksia.

\begin{tabular}{|c|c|c|}
\hline & Keskiarvo & Keskihajonta \\
\hline Lehmiä, kpl & 27 & 13 \\
\hline Keskituotos, kg/v & 8856 & 1083 \\
\hline Työ, h/lehmä/v & 137 & 53 \\
\hline Sidottu pääoma, €/lehmä & 6351 & 2482 \\
\hline $\begin{array}{l}\text { Koneet, rakennukset, } \\
\text { muut kiinteät kulut, } \\
€ / l e h m a ̈ / v\end{array}$ & 161 & 173 \\
\hline $\begin{array}{l}\text { Muuttuvat kustannukset } \\
\text { (ilman työtä), €/lehmä/v }\end{array}$ & 141 & 87 \\
\hline
\end{tabular}


Aluksi arvioitiin aineiston 1661 maitotilan suorituskykyä tehokkuusvertailulla. Tämän lisäksi laskettiin rehuntuotannon tehokkuus niiltä 577 maitotilalta, joilta tiedot oli saatavilla. Toisessa vaiheessa kehitettiin yhdessä tanskalaisten yhteistyökumppaneiden kanssa alustava maitotilojen benchmarkingtyökalu, minkä avulla yksittäinen maitotila voi vertailla tilansa suorituskykyä suhteessa haluttuun vertailuryhmään. Tässä tutkimuksessa käytettiin päätöksentekoa tukevina malleina DEA (Data Envelopment Analysis) -malleja, joiden avulla voidaan määrittää esimerkiksi maatilojen keskinäisiä suhteellisia tehokkuuksia (Färe ym. 1994; Coelli ym. 1998). Tavanomaisen panosorientoituneen DEA:n ajatuksena on tarkastella mahdollisuutta lisätä tuotosta pitäen panoskäyttö ennallaan tai vähentää panoskäyttöä pitäen tuotos ennallaan. Suunnattuja etäisyysfunktioita käyttäen tarkastelusuunta voidaan määrittää suhteellisten hintojen, tavoitetasojen tai ennalta määritettyjen benchmarkkien suhteen. Samoin voidaan ottaa huomioon esimerkiksi panoskäytön tai tuotoksen ala- ja/tai ylärajoja rajaamaan vertailujoukkoa.

DEA-mallien avulla voidaan määrittää tilojen taloudellinen - tekninen ja allokatiivinen - tehokkuus. Mallien etuna on, että niissä voidaan helposti käsitellä useita panoksia ja tuotoksia. Lisäksi tuotantoteknologiasta tarvittavat oletukset ovat suhteellisen vähäiset. Toisaalta mallien haittapuolena on perusmuodossa stokastisuuden puuttuminen. Tämä merkitsee sitä, että kaikkein suotuisimmat tapaukset määrittävät niin kutsutun tehokkaan pinnan. Näiden havaintojen tarkemman tarkastelun lisäksi (mahdollisten outlierien tunnistaminen) on tärkeää tunnistaa se viiteryhmä, johon kutakin havaintoa on mielekästä verrata. Kunkin havainnon kannalta viiteyksikön voi muodostaa joko jokin tehokkaalla pinnalla oleva yksittäinen havainto tai niiden yhdistelmä (konveksi kombinaatio).

Vertailupisteiden valinta voidaan suorittaa interaktiivisesti päätöksentekijän kanssa toimien (vrt. Bogetoft ja Nielsen 2005). Jotta analyyseista olisi hyötyä käytännön päätöksenteon tukena, tilatason tulokseen vaikuttavia tekijöitä on näiden vertailupisteiden valinnan lisäksi kyettävä tarkastelemaan yksityiskohtaisten prosessien, esimerkiksi rehuntuotannon tai ruokinnan, tasolla. Tässä voidaan edetä hierarkkisesti yleisestä tilakohtaisesta mallista yksityiskohtaiseen kunkin osaprosessin tarkasteluun. Päätöksentekijän voidaan antaa myös muuttaa päätös- ja tulosmuuttujiensa keskinäisiä painoja, jolloin hän myös vaikuttaa vertailuyksiköihinsä (Bogetoft ja Nielsen 2005).

Maidontuotannon, eli navetan sisäisen toiminnan, DEA-perustaiset tehokkuusanalyysit tehtiin OnFront-ohjelmistolla (EMQ 2000). Mallissa käytettiin kahta tuotosta (kuva 1), mitkä olivat tilalla tuotettu maitomäärä $(\mathrm{kg})$ ja muut sivutuotot $(€)$. Sivutuotot olivat mallissa rahamääräisinä ja ne koostuivat eläinten myynti- ja teurastuloista sekä eläinpääoman muutoksesta. Tuotantopanoksia olivat työ (h), karjalle syötetyt kotoiset rehut (ry) ja ostorehut (ry), muut muuttuvat kustannukset (€) ja kiinteät kustannukset (€). Maidon, työn ja rehujen hinnat olivat kunkin tilan tilakohtaisia hintoja.

TUOTANTOPANOKSET

TUOTOKSET

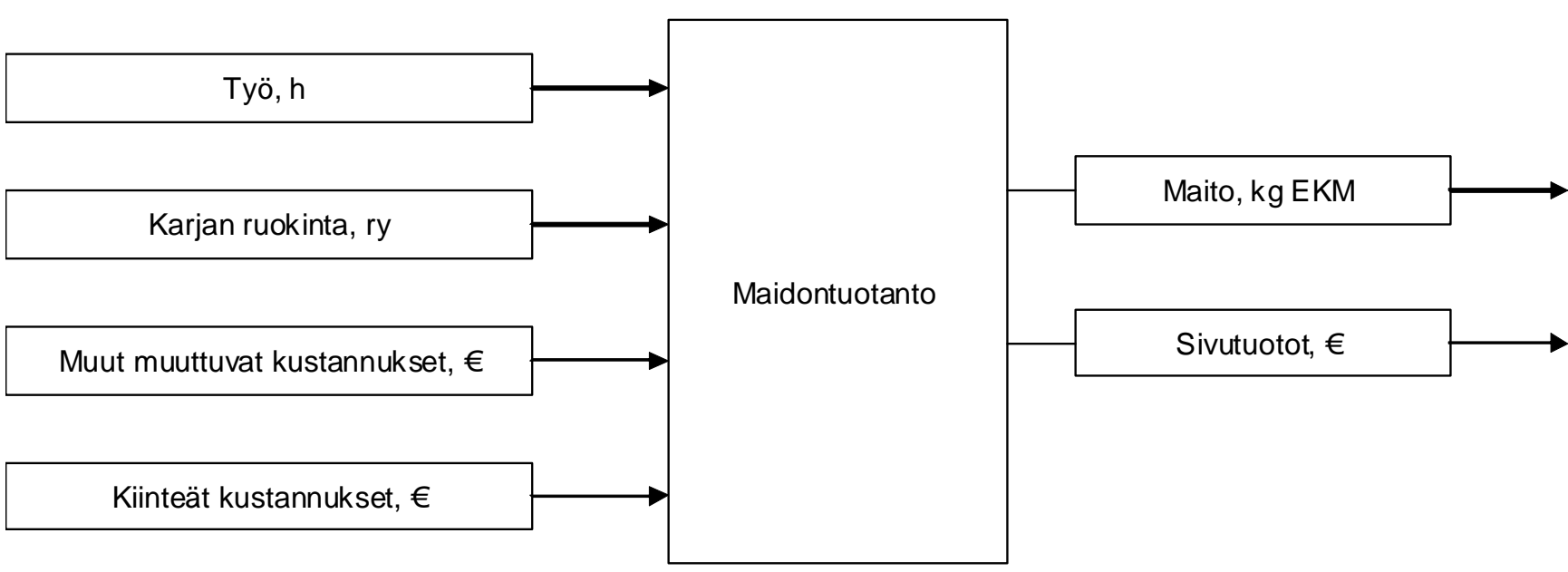

Kuva 1. Maidontuotannon tehokkuusanalyysin tuotantopanokset ja tuotokset. 
Tilojen peltoviljelystä tehtiin oma DEA-malli, jolla tehtiin tehokkuusanalyysit tilojen rehuntuotannolle. Rehuntuotantotiedot saatiin 577 maitotilalta. Tiloista poistettiin alkuvaiheessa erikoiskasveja viljelevät tilat, jolloin jäljelle jäivät pääosin nurmea ja rehuviljaa viljelevät tilat. Rehuntuotannon mallissa käytettiin yhtä tuotosta, tilan tuottamaa rehuyksikkömäärää (ry). Tuotantopanoksina olivat pelto (ha), työ (h), muut muuttuvat kustannukset (€), kiinteät kustannukset (€). Sadon arvo (€/ry) sekä työn hinta olivat kunkin tilan tilakohtaisia arvoja. Pellon käytön kustannukset määritettiin laskennallisen vuokran perusteella. Hehtaarivuokrina käytettiin tukialueittaisia keskivuokria, mitkä vaihtelivat 42-276 €/ha välillä (Myyrä 2004).

\section{Tulokset ja tulosten tarkastelu}

Tulosten perusteella suuret maitotilat olivat teknisesti pieniä tiloja tehokkaampia ja myös kustannustehokkaampia. Yli 70 lehmän tiloilla tekninen tehokkuus Fi(C,S) oli keskimäärin 0,95 ja kustannustehokkuus $\mathrm{Oi}(\mathrm{C}, \mathrm{S})$ puolestaan 0,83. Tehokkuusluvuissa C tarkoittaa laskennan vakioskaalatuottooletusta ja S panosten vapaata tuhlattavuusoletusta. Tekninen tehokkuusluku 0,95 tarkoittaa sitä, että tila voisi tuottaa saman tuotoksen $5 \%$ alemmalla panosmäärällä, jos tila voisi toimia tehokkaan vertailutilan tavoin. Vastaavasti kustannustehokkuusluku 0,83 tarkoittaa sitä, että voisi tuottaa saman tuotoksen $17 \%$ alhaisemmin kustannuksin, jos tila voisi toimia tehokkaan vertailutilan tavoin. Aineiston 50-70 lehmän tiloilla tekninen tehokkuus oli keskimäärin 0,92 ja kustannustehokkuus keskimäärin 0,84. Vastaavasti 25-50 lehmän tiloilla luvut olivat 0,86 ja 0,77 sekä alle 25 lehmän tiloilla 0,82 ja 0,67. Alle 25 lehmän tiloilla voitaisiin siten alentaa panoskäyttöä $18 \%$ ja kustannuksia $33 \%$, jos tiloilla voitaisiin toimia tehokkaan vertailutilan tavoin. Maidontuotannon yksikkökustannus oli yli 50 lehmän tiloilla keskimäärin $0,43 € / l$ ja pienimmässä alle 25 lehmän luokassa 0,58 €/l.

Kuvasta 2 nähdään maidontuotannon kustannustehokkuuden ja tilakoon yhteys tutkimusaineistossa. Spearmanin järjestyskorrelaatio $(r=0,59)$ oli näiden välillä tilastollisesti merkitsevä $1 \%$ :n riskitasolla. Yhteys on voimakas noin 400000 litraa vuodessa tuottaviin tiloihin saakka. Aineiston perusteella näyttääkin siltä, että maitotilojen kokoetu on hyödynnetty tähän vuosituotokseen mennessä. Tätä suuremmilla tiloilla kustannustehokkuuden nousu taittuu eikä maidon yksikkökustannus alene merkittävästi.

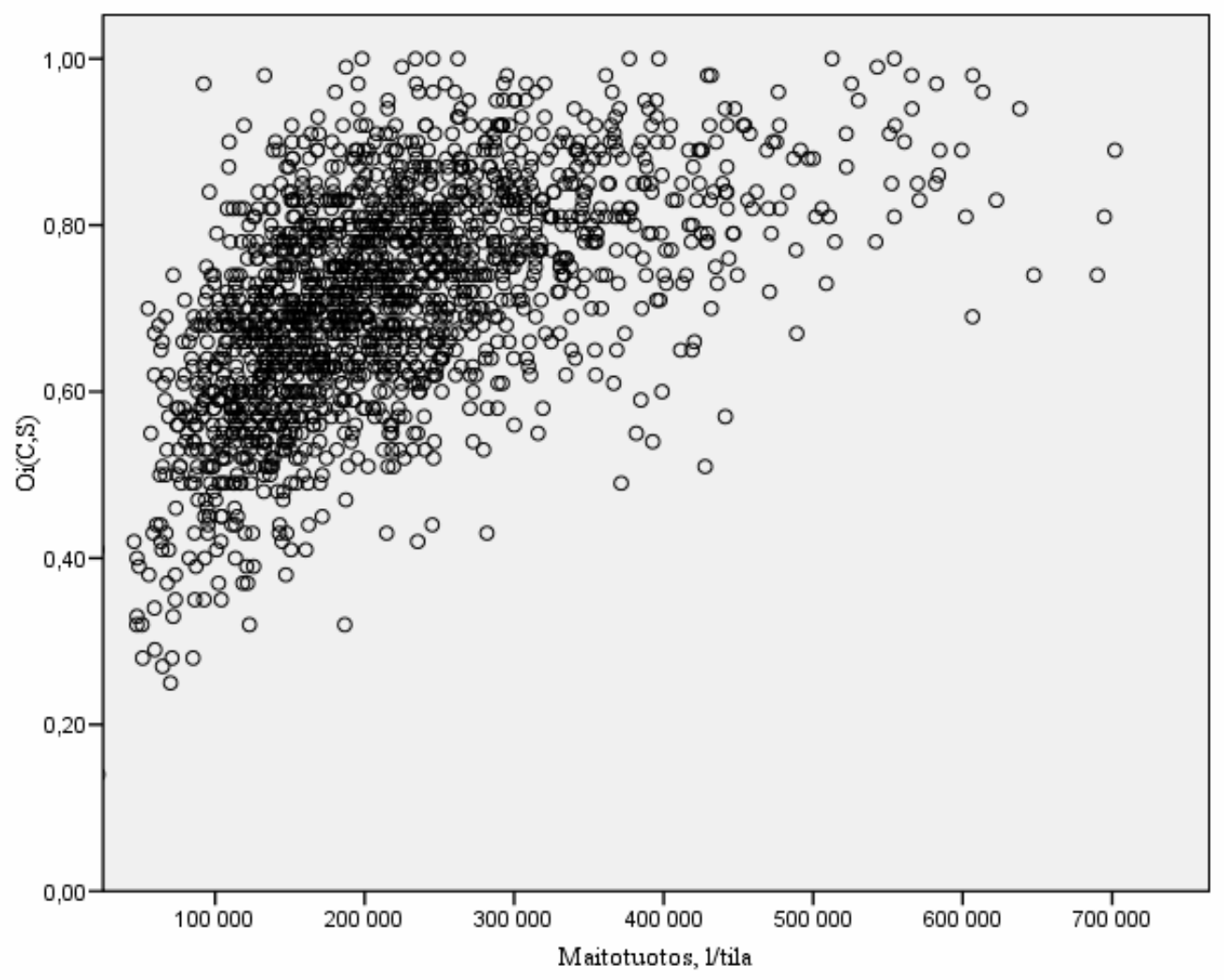

Kuva 2. Maidontuotannon kustannustehokkuuden Oi(C,S) ja maitotuotoksen yhteys. 


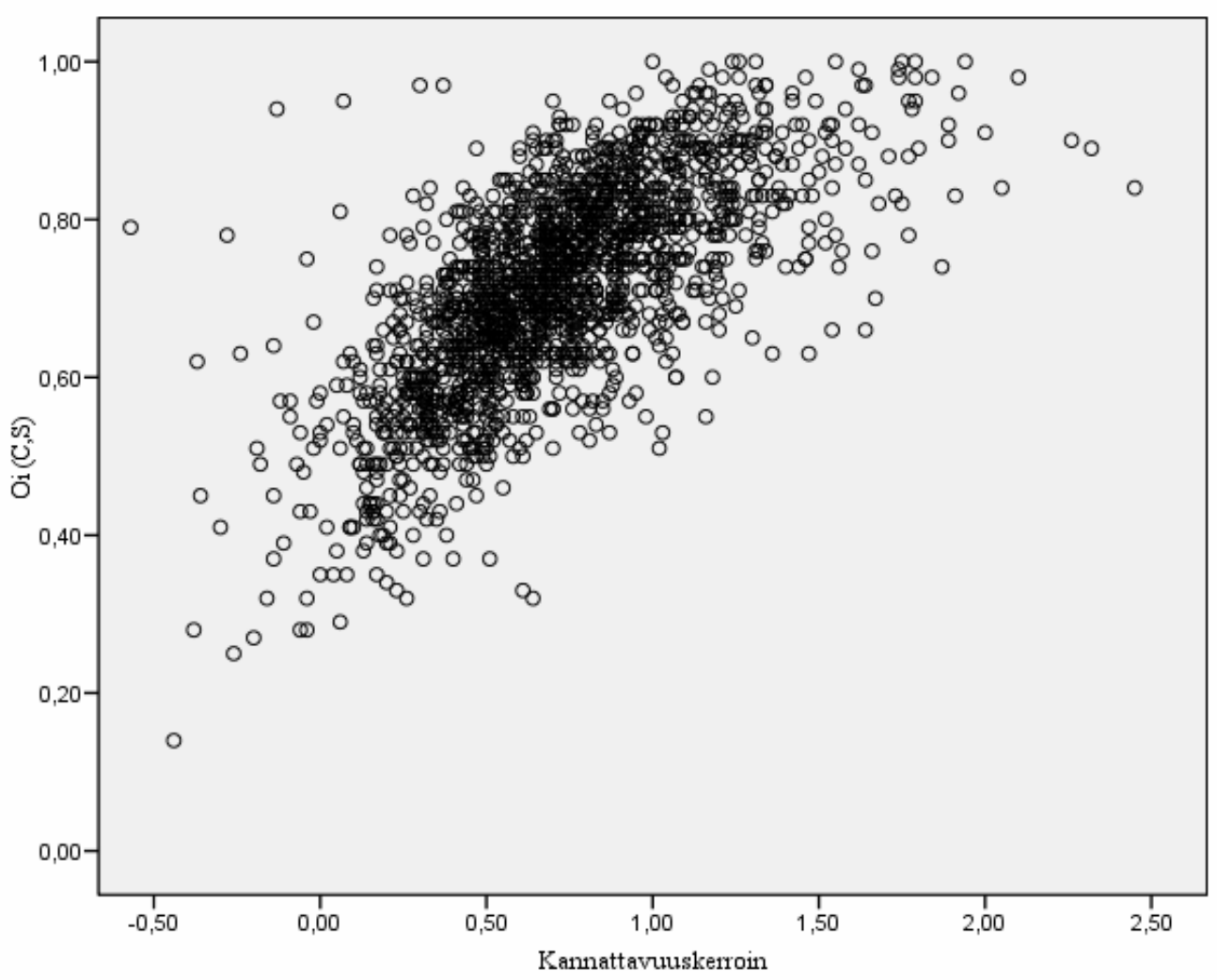

Kuva 3. Maidontuotannon kustannustehokkuuden Oi(C,S) ja kannattavuuskertoimen yhteys.

Kuvassa 3 nähdään tutkimustilojen maidontuotannon kustannustehokkuuden ja tilojen kannattavuutta kuvaavan kannattavuuskertoimen yhteys. Nämä tunnusluvut korreloivat keskenään tilastollisesti merkitsevästi $(\mathrm{r}=0,7) 1 \%$ :n riskitasolla. Aineiston 105 kustannustehokkaimmasta (yli 0,9) maitotilasta 75 \%:lla kannattavuuskerroin oli vähintään 1 ja lähes 25 \%:lla vähintään 1,5. Saman verran, noin 25 \% aineiston kustannustehokkaimmista tiloista jää kannattavuuskertoimessa alle 1:n. Siten korkeankin kustannustehokkuuden tiloilla saatettiin jäädä alle asetettujen kannattavuustavoitteiden. Toisaalta jotkin näistä tiloista saavuttivat tavoitteisiinsa nähden kaksinkertaisen korvauksen omalle työlle ja omalle pääomalle.

Vakioskaalatuotto-oletuksen vallitessa korkeita kustannustehokkuuksia esiintyy hyvin vähän alle 20 lehmän tiloilla. Aineiston 1661 maitotilasta yhteensä $35 \%$ on alle 20 lehmän tiloja. Samoin 20-30 lehmän tilojen osuus on $35 \%$. Alle 20 lehmän tiloista vain $7 \%$ on tiloja, joilla kustannustehokkuus on yli 0,9. Sen sijaan 20-30 lehmän tiloista jo $30 \%$ saavuttaa yli 0,9 kustannustehokkuuden. 3050 lehmän tilojen osuus aineistossa on $25 \%$, mutta kustannustehokkuudeltaan korkeimmista tiloista lähes puolet (46 \%) kuuluu tähän kokoluokkaan. Yli 50 lehmän tiloja on aineistossa vain $5 \%$, mutta kustannustehokkuudeltaan korkeimpien 105 tilan joukossa yli 50 lehmän tilojen osuus on 18 \%.

\section{Johtopäätökset}

Aineiston perusteella maitotilojen tekninen tehokkuus sekä kustannustehokkuus olivat suurilla tiloilla keskimäärin pieniä tiloja korkeammalla tasolla. Kuitenkin yli 400000 litraa maitoa vuodessa tuottavien tilojen ryhmässä kustannustehokkuus sekä maidon yksikkökustannus eivät enää alentuneet merkittävästi tilakoon kasvaessa. Maidontuotannon yksikkökustannukset olivat yli 50 lehmän tiloilla keskimäärin $0,43 € / l$ ja pienillä alle 25 lehmän tiloilla keskimäärin $0,58 € / l$.

Pienet tilat saivat myös harvoin korkeita kustannustehokkuuslukuja, erityisesti alle 20 lehmän tilat. Sen sijaan jo hieman suuremmat 20-30 lehmän tilat saivat merkittävästi edellistä pienintä ryhmää useammin korkeita kustannustehokkuuslukuja. Aineiston kaikkein suurimmilla tiloilla on todennäköisesti investoitu tuotantoon edellisinä vuosina, mikä osaltaan saattaa alentaa niiden kustannustehokkuutta ja nostaa niiden yksikkökustannuksia. 
Myös onnistuminen rehuntuotannossa alentaa tilalla tuotetun rehuyksikön kustannusta, mikä osaltaan vaikuttaa karjan ruokintakustannukseen. Tutkimustiloilla alhaisiin tuotantokustannuksiin (alle 0,20 $€ /$ ry, peltotukia ei huomioitu) päästiin peltoalaltaan hyvin monenkokoisilla tiloilla (25-150 ha). Toisaalta korkeimmat tuotantokustannukset keskittyivät pääosin alle 50 ha:n tiloille. Tämän vuoksi itse maidontuotannon ohella on oleellista tarkastella myös rehuntuotannon onnistumiseen vaikuttavia tekijöitä.

\section{Kirjallisuus}

Bogetoft, P. \& Nielsen, K. 2005. Internet Based Benchmarking. Journal of Group Decisions and Negotiations 14: $195-215$.

Coelli, T., D. Prasado Rao \& G.E. Battese 1998. An Introduction to Productivity and Efficiency Analysis, Kluwer Academic Publishers.

EMQ 2000. On Front 2.0. The Professional Tool For Efficiency and Productivity Measurement. Economic Measurement and Quality in Lund Corporation.

Färe, R., S. Grosskopf \& C.A.K. Lovell. 1994. Production Frontiers.

Hardaker, J.B., R.B.M. Huirne \& J.R. Andersson 1997. Coping with risk in agriculture.

Myyrä, S. 2004. Pellon vuokrahinnat Suomessa vuosina 2003-2004. MTT selvityksiä 75.23 s. 